\title{
CARDIORENAL SYNDROME TYPE 1: DEFINITION, ETIOPATHOGENESIS, DIAGNOSTICS AND TREATMENT
}

Tomislav Nikolic ${ }^{1,3}$, Milan Radovanovic ${ }^{2,3}$, Miodrag Sreckovic ${ }^{2,3}$, Marina Markovic ${ }^{3}$, Dejan Petrovic ${ }^{1,3}$ ${ }^{1}$ Center for nephrology and dialysis, Clinical center "Kragujevac", Kragujevac, Serbia ${ }^{2}$ Clinic for Cardiology, Clinical center "Kragujevac”, Kragujevac, Serbia

${ }^{3}$ Department of Internal medicine, Faculty of Medical Sciences, University of Kragujevac, Serbia

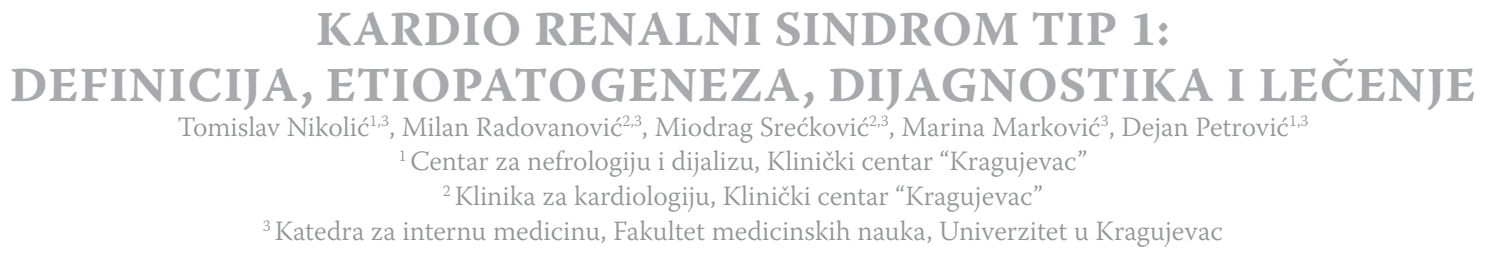

\section{ABSTRACT}

Cardiorenal Syndrome Type 1 (CRS-1) is defined as an acute worsening of heart function leading to acute kidney injury and/or dysfunction. It is an important cause of hospitalization which affects the diagnosis as well as the prognosis and treatment of patients. The purpose of this paper is to analyze causes that lead to the development of cardiorenal syndrome type 1 and its clinical consequences, as well as to emphasize the clinical importance of its early detection. The clinical studies and professional papers dealing with etiopathogenesis, diagnosis and treatment of cardiorenal syndrome type 1, have been analyzed. The most important role in the occurrence of cardio renal syndrome type 1 is played by hemodynamic mechanisms, activation of neurohumoral systems, inflammation and imbalance between the production of reactive oxygen species (ROS) and nitric oxide (NO). Diagnosis of cardiorenal syndrome type 1 involves biomarkers of acute renal injury among which the most important are: neutrophil gelatinaseassociated lipocalin (NGAL), cystatin C, kidney injury molecule 1 (KIM-1), liver-type fatty acid binding protein (L-FABP), IL-18 and the values of nitrogen compounds in serum. In addition to a pharmacological therapy, various modalities of extracorporeal ultrafiltration are applied in treatment of CRS-1, particularly if there is resistance to the use of diuretic therapy. As opposed to the experimental models, in clinical practice acute renal injury is often diagnosed late so that the measures taken do not give the expected results and the protective role shown in experimental conditions do not give the same results. For all these reasons, it is necessary to analyze the pathophysiology of renal impairment in cardiorenal syndrome as well as detect early indicators of kidney injury that could have clinical benefit and positive impact on reducing the cost of treatment.

Keywords: cardiorenal syndrome, diagnosis, treatment, therapy

\section{SAŽETAK}

Kardiorenalni sindrom tip 1 (KRS - 1) se definiše kao akutno pogoršanje funkcije srca koje dovodi do akutnog oštećenja i/ ili poremećaja funkcije bubrega. Predstavlja važan uzrok hospitalizacije koji utiče kako na dijagnozu, tako i na prognozu i lečenje pacijenata. Rad je imao za cilj da analizira faktore koji dovode do nastanka kardiorenalnog sindroma tip 1, kliničke posledice i da ukaže na klinički značaj njegovog ranog otkrivanja. Analizirane su kliničke studije i stručni radovi koji se bave etiopatogenezom, dijagnostikom i lečenjem kardiorenalnog sindroma tip 1. U nastanku kardiorenalnog sindroma tip 1 najznačajniju ulogu imaju hemodinamski mehanizmi, aktivacija neurohumoralnih sistema, inflamacija i poremećaj ravnoteže između stvaranja slobodnih radikala kiseonika (ROS) i azot monoksida (NO). Dijagnostika kardiorenalnog sindroma tip 1 uključuje određivanje biomarkera oštećenja bubrega u serumu među kojima su najznačajniji: NGAL (serumski lipokalin povezan sa želatinozom neutrofila), cistatin C, molekul oštećenja bubrega 1 (KIM-1), jetreni transportni protein masnih kiselina (L-FABP), IL -18 kao i vrednosti azotnih materija u serumu. Pored primene farmakološke terapije u lečenju se primenjuju i različiti modaliteti vantelesne ultrafiltracije, naročito ukoliko postoji rezistencija na primenu diuretske terapije. Nasuprot eksperimentalnim modelima u kliničkoj praksi se akutno oštećenje bubrega kasno dijagnostikuje tako da mere koje imaju benefita i protektivnu ulogu u njegovom nastanku u eksperimentalnim uslovima ne daju iste rezultate u kliničkoj praksi. Zbog svega pomenutog potrebno je analizirati patofiziologiju renalnog oštećenja u KRS-u kao i otkriti raniji indikator oštećenja bubrega što bi moglo imati ranu kliničku korist $i$ uticalo na smanjenje troškova lečenja.

Ključne reči: kardiorenalni sindrom, dijagnostika, lečenje, terapija
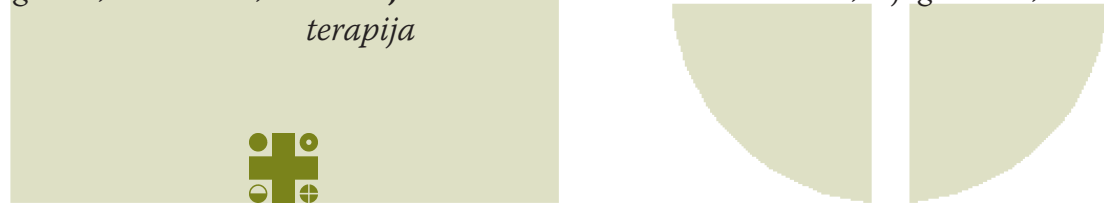


\section{ABBREVIATIONS}

ADHF - acute decompensated heart failure CRRT - continuous renal replacement therapy SCUF - slow continuous ultrafiltration CVVHF - continued veno-venous hemofiltration CRS-1 - cardiorenal syndroma type 1 GFR - glomerular filtration rate KIM-1 - kidney injury molecule 1

\section{INTRODUCTION}

Cardiorenal syndrome type 1 (CRS-1) is defined as an acute worsening of the heart function leading to an acute kidney injury and/or renal dysfunction. It is an important cause of hospitalization which affects the diagnosis as well as the prognosis and treatment of patients, increasing the risk of cardiovascular mortality and morbidity, cerebrovascular insult, duration of hospitalization and the frequent need of rehospitalization. It occurs in $25-33 \%$ of patients hospitalized for acute heart failure $(1,2)$. Conditions that lead to rapid deterioration of cardiac function are acute hypertensive pulmonary edema with preserved systolic function, acute decompensation of chronic heart failure, cardiogenic shock and acute predominant right ventricular failure (3-10) (Table 1).

\section{Etiopathogenesis}

There are direct and indirect effects of heart failure that are designated as primary for the occurance and incidents of acute renal injury as well as renal dysfunction. The factors hidden behind the classic hemodynamic mechanisms
L-FABP - liver-type fatty acid binding protein

IL-1, IL-6, IL-18 - interleukin 1, 6, 18

NGAL - neutrophil gelatinase-associated lipocalin NO - nitric oxide

RAAS - renin angiotensin aldosterone system

ROS - reactive oxygen species

$\mathrm{SCr}$ - serum creatinine

TGF - tubuloglomerular feedback mechanism

play the main role in the pathogenesis of renal impairment. The factors involved in the development of cardiorenal syndrome type 1 are: venous congestion, dysfunction of the sympathetic nervous system, anemia, activation of the renin angiotensin aldosterone system (RAAS), disruption of the hypothalamic-pituitary axis and significant changes in immune and somatic cell signaling (Table 1) (11). In addition to the aforementioned mechanisms, renal impairment occurs as a result of renal hypoperfusion, which occurs as a consequence of reduced cardiac output and systemic arterial pressure. A sudden decrease of intravascular volume activates the renin angiotensin aldosterone system (RAAS), which leads to an increase in angiotensin 2 , which stimulates creation and release of endothelin 1 in kidneys, a strong profibrotic inflammatory and vasoactive peptide which plays an important role in most pathogenetic mechanisms of acute kidney injury (3-9). All this leads to a decrease in glomerular filtration rate and development of acute kidney injury.

\section{Venous congestion}

Venous congestion is one of the most important hemodynamic determinants of cardiorenal syndrome which is

Table 1. Ethipathogenesis and biomarkers in Cardiorenal syndroma type 1

\begin{tabular}{|c|c|c|}
\hline \multicolumn{3}{|c|}{ Cardio renal sindroma type 1} \\
\hline The main couses & Pathogenesis & Biomarkers \\
\hline $\begin{array}{l}\text { 1. Acute hypertensive } \\
\text { pulmonary edema with } \\
\text { preserved systolic function } \\
\text { 2. Acute decompensation of } \\
\text { chronic heart failure } \\
\text { 3. Cardiogenic shock } \\
\text { 4. Acute predominant right } \\
\text { ventricular failure }\end{array}$ & $\begin{array}{l}\text { Factors that lead to renal hypoperfusion: } \\
\text { 1. Dysfunction of the sympathetic nervous system } \\
\text { 2. Venous congestion } \\
\text { 3. Anemia } \\
\text { 4. Activation of the RAAS } \\
\text { 5. Disruption of the hypothalamic-pituitary axis } \\
\text { 6. Significant changes in immune and somatic cell signaling } \\
\text { 7. Imbalance between the production of reactive oxygen species (ROS) and nitric oxide (NO) } \\
\text { 8. Inflamation (c-reactive protein, pentraxin } 3 \text {, tumor necrosis factor } \alpha, \mathrm{IL}-1 \text {, and IL-6 } \\
\text { 9. Apoptotic factors in plasma (caspase-3 and caspase } 8 \text { ) }\end{array}$ & $\begin{array}{l}\text { 1. NGAL } \\
\text { 2. Cystatin C } \\
\text { 3. KIM-1 } \\
\text { 4. L-FABP } \\
\text { 5. IL - } 18\end{array}$ \\
\hline
\end{tabular}

RAAS - renin angiotensin aldosterone system

NGAL- Neutrophil gelatinase-associated lipocalin

KIM-1 Kidney injury molecule

L-FABP- Liver fatty acid binding protein

IL-18- interleukin 18

IL-1 interleukin 1

IL-6 interleukin 6 
associated with a renal dysfunction within the acute decompensated heart failure (12). Neurohormonal activation flooding atrio-renal reflexes in patients with heart failure is manifested by persistent renal retention of sodium and water in spite of atrial pressure. Transmission of venous congestion to renal veins continues to threaten glomerular filtration rate (GFR) (13). One of the possible mechanisms that connects venous congestion and GFR is an increase in renal interstitial pressure that leads to an increased concentrations of angiotensin II which results in a reduction in the glomerular filtration rate, either directly or via modulation of the sympathetic nervous system. The stimulation of the adrenergic receptors on the proximal tubule renal cells increases the reabsorption of sodium, while the stimulation of the adrenergic receptors in the juxtaglomerular apparatus stimulates RAAS (14).

The most important non-hemodynamic mechanisms involved in the development of CRS-1 are: renin angiotensin aldosterone system (RAAS), the sympathetic nervous system (SNS), inflammation and an imbalance between the production of reactive oxygen species (ROS) and nitric oxide (NO) (15).

\section{Inflamation and immune cell signaling}

Inflammation plays an important role in the development of all types of cardiorenal syndrome, including type one. Numerous studies have demonstrated the activation of different levels of inflammation in patients with heart failure. Acute heart failure leads to an immune activation and production of cytokines, complement system, TNFalpha, adhesion molecules and immune cells, which cause damage to distant organs such as kidneys, leading to acute renal injury, exacerbating the heart failure. The inflammatory cytokines which can be created in the myocytes as a result of an ischemic or mechanical stimuli or innate immune response that is represented as a "toll-like" receptor, "pentraxin-like" C-reactive protein and pentraxin 3 (16-18) provide an inflammatory etiology of heart failure. The increase of cytokines, as well as inflammatory markers, in the blood have been proven in patients with acute decompensated heart failure (19). There is evidence which supports the prognostic value of various circulating markers of inflammation, particularly C-reactive protein, pentraxin 3, tumor necrosis factor $\alpha$, IL-1, and IL-6 (20). For example, it has been shown that high levels of C-reactive protein, an acute phase reactant, are registered in the last stages of renal failure (21). A study conducted by Pastori and his colleagues showed that the development of CRS-1 is immune-mediated and that loss of normal regulation of the immune system may play a role in the pathogenesis of CRS-1. The study pointed to a high activity of apoptotic factors in plasma of patients with CRS-1 (caspase-3 and caspase 8 - inducing apoptosis of monocytic cells) as well as high levels of IL- 6 and IL-18 (22). These findings suggest an immunological basis for CRS-1 because various cardiorenal mediators can induce early pathological apoptosis of monocytes.

\section{The predisposing factors for type $1 \mathrm{CRS}$}

There are variety of contributing factors that pose a risk for the development of cardiorenal syndrome type 1. Obesity and cardiometabolic changes in the cardiovascular system, including diabetes, hypertension, and subsequently, during the illness cachexia, biochemical and hormonal changes caused by disorders of bone and mineral metabolism, retention uremic molecules, proteinuria and anemia - these all are involved in the development of CRS-1. The development of this syndrome can cause permanent renal impairment and the need for dialysis or a partial renal recovery. Coronary revascularization also leads to a development of cardiorenal syndrome type 1 . Before surgical vascularization each patient undergoes coronary angiography. Iodinated contrast agents cause renal vasoconstriction and direct toxicity of the renal tubules. As a result, contrast-induced nephropathy occurs in $15 \%$ of patients (23). During surgical revascularisation of the heart, kidneys are exposed to hypothermia, absence of pulse, perfusion reduction of 30-90 minutes, which can lead to progression of ischemic injury in the ambient of proinflammatory condition. It is possible that extracorporeal circulation used in the cardiovascular surgery triggers systemic factors that further lead to the acute renal injury. Attempts to reduce exposure to this risk did not lead to a reduction in incidence of acute kidney injury (24). Cardiac bypass surgery with acute renal impairment occurs in $30 \%$ of patients. The cardiorenal syndrome type 1 causes an increase in mortality rate three to four times despite the possibility of dialysis (25).

\section{Diagnostics of cardiorenal syndrome type 1}

The latest biochemical biomarkers, whose values are increased even at a slight reduction in kidney function, are used in the early diagnosis of type 1 CRS. What should not be ignored is the increase in serum creatinine in the diagnosis of acute kidney injury. Thus cardiorenal syndrome type 1 is defined as an increase in serum creatinine compared to the value at the time of admission to $26.5 \mu \mathrm{mol} / \mathrm{L}$ and more or $44.2 \mu \mathrm{mol} / \mathrm{L}$ and more or $25 \%$ and more, as well as an increase in the value of the SCr by $50 \%$ SCr values at the time of admission or as a combined increase in $\mathrm{SCr}$ of $26.5 \mu \mathrm{mol} / \mathrm{L}$ and more or $25 \%$ and more (26). In the last decade, several risk scores for acute kidney injury in patients with acute heart failure, acute myocardial infarction and in patients undergoing cardiac surgery or coronary angiography have been published. The application of these scores in clinical work has shown great benefit in the prevention of CRS-1 (27). Forman (28) and Mehran (29) risk scores are widely used in the world. They are very valuable for predicting the emerging acute renal injury in patients with acute decompensated heart failure and those who underwent coronary angiography. Risk factors included in risk scores were: age, serum creatinine levels, systolic arterial pressure, glomerular filtration rate, diabetes mellitus, use of furosemide and many others. 


\section{Biochemical markers of acute renal injury}

Serum creatinine, glomerular filtration rate determined by creatinine clearance, the concentration of sodium in the urine, fractional excretion of sodium, fractional excretion of urea, and urine osmolality are used as standard laboratory parameters in clinical practice. In addition to the parameters listed, for early detection of acute kidney injury in recent years some new biomarkers have been used: KIM-1 - kidney injury molecule 1, L-FABP - the liver fatty acid binding protein, IL -18, NGAL and cystatin C (30). A larger number of studies have examined the role of biomarkers in predicting the occurrence of cardiorenal syndrome type 1 in patients with acute decompensated cardiac insufficiency (Table 1) (31). In their study Pfister and colleagues found elevated basal NT-proBNP as a predictor for developing acute renal impairment (32).

\section{$N G A L$}

In one of the numerous studies, on admission, among patients who had developed acute renal failure, the increased serum neutrophil gelatinase-associated lipocalin (NGAL) was shown. NGAL is a protein mass of $25 \mathrm{kDa}$, and is one of the important indicators of acute renal injury and is very often used in clinical practice (33). If the values of NGAL in the urine are greater than $100 \mathrm{ng} / \mathrm{ml}$ two hours after the initial event, it indicates the development of acute renal impairment (34). NGAL serum values are determined by the impairment of renal function rather than myocardial function (35). In patients with ADHF (acute decompensated heart failure) serum NGAL largely correlates with renal functional markers. High values of NGAL on hospital admission are associated with adverse cardiovascular outcomes or death.

\section{Cystatin C}

Serum cystatin $C$ measured on admission of patients with acute decompensated heart failure is a better longterm predictor of mortality and rehospitalization than serum creatinine or BNP (36). Cystatin C is a cysteine protease inhibitor which is completely reabsorbed in the proximal tubule cells. It proved to be a very sensitive indicator of small changes in glomerular filtration rate. This biomarker is an independent predictor of adverse cardiac events in patients with acute coronary syndrome (37). Its concentration is increased up to two days before the increase of serum creatinine concentration. Due to its predictive values and biochemical characteristics serum cystatin $\mathrm{C}$ may also be of great relevance for the diagnosis of early loss of kidney excretory function in CRS-1.

\section{Treatment of CRS-1}

The treatment of CRS type 1 is rather complex and the consensus on the choice of an appropriate therapeu- tic approach has not been reached yet. It was agreed that the preservation of renal function should have the same priority as the preservation of heart function (38). Standard therapeutic strategies in clinical practice imply medical therapy and open ultrafiltration dialysis supportive therapy.

\section{Medical therapy}

The usage of medications for the treatment of heart failure, such as diuretics, ACE inhibitors, and angiotensin receptor blockers have a deleterious effect on renal function. Diuretics improve symptoms in acute decompensated heart failure and in the long run they do not affect morbidity and mortality, but they may lead to a deterioration of renal function, due to neurohumoral activation. These patients often experience resistance to these drugs as well as the absence of desired effect. Resistance occurs due to the reduction of glomerular filtration, activation of the sympathetic nervous system and RAAS system, hypertrophy of epithelial cells of the distal tubules and increased concentration of adenosine. Loop diuretics are the first-line drugs for patients with acute decompensated heart failure, where volume overload is present, with the goal of acheaving a gradual diuresis (39). Dosing of diuretics depends on renal function, systolic blood pressure and previous treatment with diuretics. Diuresis can be enhanced by the addition of thiazide diuretic, acetazolamide, spironolactone or by using continuous infusion of loop diuretics. Continuous infusion of diuretics can be monitored by using the techniques to evaluate the quantity of liquids such as bioelectrical impedance vector analysis (BIVA), measuring proBNP, cardiac output and central venous pressure. According to a study conducted by Felker et al. it has been proven that in patients with acute decompensated heart failure (ADHF) there is no significant difference in improvement of symptoms, the number of rehospitalizations and deaths between those in which diuretics are administered by continuous IV infusion and those who received the bolus, nor were there diffeences in the application of high versus low doses of diuretics (40). Beta blockers are administered with caution, especially in patients with cardiogenic shock. Their application should be started cautiously, when hemodynamic stability of patient is established, particularly in patients with CRS-1 after myocardial infarction (41). ACE inhibitors and angiotensin receptor blockers are underused in the treatment of cardiorenal syndrome due to fears of worsening renal function. Blockade of RAAS alone reduces morbidity and mortality in patients with chronic heart failure and slowing the progression of chronic renal failure, particularly in patients with diabetic nephropathy (42). The use of ACE inhibitors in patients with moderate renal failure has a positve effect on their survival rate despite a transient worsening of renal function that occurs in $30 \%$ of cases. The presence of acute renal failure with or without hypokalemia can also reduce the use of the ACE inhibitors and the aldosterone receptor blockers. In 
patients with severe renal insufficiency a constant monitoring of renal function is required because of unknown relations between their safety and efficacy. Apart from the drugs mentioned, in the treatment of CRS-type1 the inotropic drugs are used, among including dopamine, dobutamine, norepinephrine, fenodolpan. Dopamine is a remedy which, depending on the dose, may have vasodilator, inotropic and systemic vasoconstrictor effects. It is used in patients with systemic hypotension and in patients with reduced cardiac index (43).

\section{Newer drugs for the treatment of type 1 CRS}

New strategies in the treatment of CRS 1 involving use of drugs that improve kidney function in patients with heart failure and those are adenosine receptor antagonists and vasopressin antagonists. The blockade of subtype 1 adenosine receptors can enhance diuresis and natriuresis with maintaining or increasing GFR and reduce the need for loop diuretics (44). The blockade of adenosine receptors leads to a blockade of tubuloglomerular feedback mechanism (TGF) which is responsible for normal homeostasis of electrolytes and fluids that can be changed in heart failure and leads to a diuretic resistance and reduction of glomerular filtration rate. A placebo-controlled, randomized study showed that selective adenosine A1 receptor blockers such as rolofylline in patients hospitalized with ADHF and volume overload in order to assess the effect on congestion and renal function was not better than placebo (45). Although it showed an improvement of dyspnea, rolofilline did not prevent the emergence of kidney damage nor had a significant effect on the overall success of treatment. The blockade of vasopressin V2 receptors in collecting ducts of kidneys leads to an increase in the excretion of free fluid which can theoretically correct fluid retention and hyponatremia in patients with congestive heart failure. Tolvaptan, an oral selective vasopressin V2 receptor antagonist, showed results in improving symptoms, but not in reducing the number of rehospitalizations and mortality in patients with ADHF (46). Conivaptan is antagonist of both vasopressin V1 and V2 receptors which not only reduces the excretion of fluids but it can also reduce systemic vascular resistance and improve systolic function (47). Natriuretic peptides have systemic and renal vasodilator effect, natriuretic, diuretic and myorelaxant effect on smooth muscles and they reduce the need for oxygen in certain segments of the nephron (48). The synthetic natriuretic peptides lead to a dilatation of the arterial and venous systems. The study ASCEND - HF (Acute Study of Clinical Effectiveness of Nesiritide and decompensated Heart Failure) which studied the effect of Nesiritide B, a synthetic natriuretic peptide, in patients with decompensated heart failure showed that Neseritide B has no effect on survival rate, as well as on the number of rehospitalizations (49). Urodilantin A is a natriuretic peptide which can improve symptoms but does not affect the mortality and renal function in patients with ADHF (acute decompensated heart failure) (50).

\section{Ultrafiltration in treatment of type 1 CRS}

Ultrafiltration is indicated if the volume overload persists despite an optimal output and the application of diuretic therapy and when there is resistance to its use. The process of ultrafiltration removes the isotonic fluid from the blood of patients, wherein there is no activation of the sympathetic nervous system and the renin-angiotensinaldosterone system $(51,52)$. There are several modalities of ultrafiltration used in the treatment of patients with an acute worsening of chronic heart failure and these are Aquadex system, Intermittent Ultrafiltration - IUF and Slow Continuous Ultrafiltration - SCUF. According to the study RAPID-CHF ("Relief for Acutely Fluidity Overload Patients with Decompensated CHF") the application of SCUF showed good results in patients with a sudden worsening of chronic heart failure (53). The Continued Veno Venous Hemofiltration (CVVHF) has found its application in patients with a sudden worsening of chronic congestive heart failure, metabolic disorders of electrolyte and acidbase balance (hyperkalemia, metabolic acidosis), as well as in the removal of excess fluids.

Comparison of efficacy of diuretic therapy and ultrafiltration by open dialysis supportive therapy in the treatment of type 1 CRS

A study called UNLOAD (The Ultrafiltration versus IV Diuretics for patients Hospitalized for Acute decompensated Congestive Heart Failure) compared the application of ultrafiltration with the application of diuretics in patients with acute decompensated cardiac failure. Ultrafiltration has reduced the number of rehospitalizations and increased weight loss in patients with ADHF (54). Another smaller study, conducted by Rogers and associates showed no difference in the balance of fluid, glomerular filtration rate and renal plasma flow between the application of ultrafiltration and loop diuretics (55). In a four-year period the large study CARRES-HF (2008-2012) showed that the application of the step-approach pharmacological therapy is superior to ultrafiltration regarding preserving renal function during $96 \mathrm{~h}$ in patients with acute decompensated heart failure, worsening of renal function and persistent congestion (56). The use of ultrafiltration has been associated with a number of adverse events (bleeding, worsening of renal function, complications associated with IV catheter). Weight loss was similar in both groups. In addition to the aforementioned, two smaller studies have also shown that the use of methods of ultrafiltration or so-called (CRRT) - Continuous Renal Replacement Therapy - is associated with a high mortality rate, especially in the simultaneous administration of vasopressors in patients over 70 years of age (57). One of these studies, conducted in Cleveland, has shown that the application of slow continuing ultrafiltration (SCUF) in patients with acute decompensated heart failure, despite the fact that it has demonstrated significant weight loss and improvement of central and venous hemodynamic parameters, did 
not show significant improvement of renal function in reducing serum creatinine and urea (58). According to these studies it can be concluded that the development of cardiorenal syndrome type 1 does not only involve hemodynamic mechanisms, but also some other, still unknown variables, suggesting that the improvement in haemodynamic parameters is not closely related to the amelioration of renal function (59).

\section{Peritoneal dialysis in cardiorenal syndroma type 1}

Peritoneal dialysis provides better hemodynamic stability in patients with acute exacerbation of chronic congestive heart failure and acute kidney injury (60). The main advantages of peritoneal dialysis are the preservation of renal function, less variable ultrafiltration, hemodynamic stability, better clearance of large molecules, smaller loss of sodium and preservation of its normal concentration in the serum (61). The disadvantages of peritoneal dialysis are an increased risk for the development of peritonitis, metabolic disorders (hyperlipidemia, increased atherogenic potential). The results of new well-controlled, randomized clinical trials should more accurately determine the significance, place and role of peritoneal dialysis in the treatment of patients with cardio-renal syndrome type 1 (62).

\section{CONCLUSION}

The clinical significance of acute kidney injury, when the outcome of treatment of patients is in question, has increased in recent years. Deterioration of renal function in patients with acute decompensated heart failure is an important risk factor and very often results in a rapid deterioration of the clinical picture. In contrast to experimental models, in clinical practice, acute renal failure is often diagnosed too late so that the measures that normally have beneficial effects and protective role under the experimental conditions do not give the same results in clinical practice. For all these reasons it is necessary to analyze the pathophysiology of renal impairment in the CRS as well as detect early indicators of kidney damage. Then the application of various protective molecules could have early clinical benefits.

\section{REFERENCES}

1. Ronco C, McCullough PA, Anker SD, et al. Acute Dialysis Quality Initiative (ADQI) Consensus Group. Cardiorenal syndromes: an executive summary from the Consensus Conference of the Acute Dialysis Quality Initiative (ADQI). Contrib Nephrol 2010; 165: 54-67.

2. Hata N, Yokoyama S, Shinada T, et al. Acute kidney injury and outcomes in acute decompensated heart failure: evaluation of the RIFLE criteria in an acutely ill heart failure population. Eur J Heart Fail 2010; 12: 32-7.
3. Ronco C, Haapio M, House AA, Anaveker N, Bellomo R. Cardiorenal Syndrome. J Am Coll Cardiol 2008; 52(19): 1527-39.

4. Ronco C, House AA, Haapio M. Cardiorenal syndrome: refining the definition of a complex symbiosis gone wrong. Intensive Care Med 2008; 34(5): 957-62.

5. Ronco C, Chionh C-Y, Haapio M, Anavekar NS, House A, Bellomo R. The Cardiorenal Syndrome. Blood Purif 2009; 27(1): 114-26.

6. Poskurica M. Cardiorenal syndrome: definition, ethyopatogenesis, clinical manifestations, diagnostic, prevention and therapy. In: Acure renal failure: prevention, dijagnostic, therapy. Poskurica M. Ed : 77-106. Medical faculty Kragujevac, Inter print Kragujevac, Kragujevac, 2009. (in Serbian)

7. Ronco C, Haapio M, House AA, Anavekar N, Bellomo R. Cardiorenal Syndrome. In: Cardionephrology 4. Radenković S. Ed.: 13-29. GIP "PUNTA“, Niš, 2009.

8. Ronco C, McCullough PA, Anker SD, Anand I, Aspromonte N, Bagshaw SM, et al. Cardiorenal Syndromes: An Executive Summary from the Consensus Conference of the Acute Dialysis Quality Initiative(ADQI). In: Cardiorenal Syndromes in Critical Care. Ronco C, Bellomo R, McCullough PA (eds). Contrib Nephrol. Basel, Karger, 2010; 165: 54-67.

9. Teerlink JR. Diagnosis and Management of Acute Heart Failure. In: Braunwald's Heart Disease. Libby P, Bonow RO, Mann Douglas L, Zipes DP, Braunwald E. (eds). Philadelphia: Saunders Elsevier, 2008: 583-610.

10. Petrović D, Jagić N, Miloradović V, Nikolić A, Stojimirović B. Cardiorenal syndrome - definition, classification and basic principles of therapy. Ser J Exp Clin Res 2010; 11(2): 67-71.

11. Ronco C, Cicoira M, McCullough P A. Cardiorenal syndrome type 1: pathophysiological crosstalk leading to combined heart and kidney dysfunction in the setting of acutely decompensated heart failure. J Am Coll Cardiol 2012; 60: 1031- 42.

12. Mullens W, Abrahams Z, Francis GS, et al. Importance of venous congestion for worsening of renal function in advanced decompensated heart failure. J Am Coll Cardiol 2009; 53: 589-96.

13. Costanzo MR, Jessup M. The cardiorenal syndrome: do we need a change of strategy or a change of tactics? J Am Coll Cardiol. 2009; 53 (7): 597-9.

14. Kopp UC, DiBona GF. Neural regulation of renin secretion. Semin Nephrol 1993; 13: 543-51.

15. Haase M, Müller C, Damman K, Murray PT, Kellum JA, Ronco $\mathrm{C}$, et al. Pathogenesis of cardiorenal syndrome type 1 in acute decompensated heart failure: Workgroup statements from the eleventh consensus conference of the acute dialysis quality initiative (ADQI). Contrib Nephrol 2013; 182 : 99-116.

16. Frantz S, Ertl G, Bauersachs J. Mechanisms of disease: toll-like receptors in cardiovascular disease. Nat Clin Pract Cardiovasc Med 2007; 4: 444-54. 
17. Torre-Amione G. Immune activation in chronic heart failure. Am J Cardiol 2005; 95: 3C-8C.

18. Mantovani A, Garlanda C, Bottazzi BP, et al. The long pentraxin PTX3 in vascular pathology. Vascul Pharmacol 2006; 45: 326-30.

19. Milo O, Cotter G, Kaluski E, et al. Inflammatory and neurohormonal activation in cardiogenic pulmonary edema: implications on the pathogenesis and outcome of acute ischemic versus non-ischemic acute heart failure. Am J Cardiol 2003; 92: 222-6.

20. Gullestad L, Aukrust P. Review of trials in chronic heart failure showing broad-spectrum anti-inflammatory approaches. Am J Cardiol 2005; 95: 17C-23C, discussion $38 \mathrm{C}-40 \mathrm{C}$.

21. Arici M, Walls J. End-stage renal disease, atherosclerosis, and cardiovascularmortality: Is $\mathrm{C}$-reactive protein the missing link? Kidney Int 2001; 59: 407-14.

22. Pastori S, Virzì GM, Brocca A, de Cal M, Clementi A, Vescovo G, et al. Cardiorenal syndrome type 1: a defective regulation of monocyte apoptosis induced by proinflammatory and proapoptotic factors. Cardiorenal Med 2015; 5(2): 105-15.

23. McCullough PA. Contrast-induced acute kidney injury. J Am Coll Cardiol 2008; 51(15): 1419-28.

24. Diez C, Haneya A, Brünger F, et al. Minimized extracorporeal circulation cannot prevent acute kidney injury but attenuates early renal dysfunction after coronary bypass grafting. ASAIO J 2009; 55(6): 602-7.

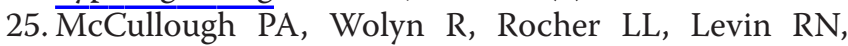
O'Neill WW. Acute renal failure after coronary intervention: Incidence, risk factors, and relationship to mortality. Am J Med 1997; 103 : 368 -75.

26. Metra M, Nodari S, Parrinello G, et al. Worsening renal function in patients hospitalised for acute heart failure: clinical implications and prognostic significance. European Journal of Heart Failure 2008; 10(2): 188-95.

27. Cheng H, Chen YP. Clinical prediction scores for type 1 cardiorenal syndrome derived and validated in chinese cohorts. Cardiorenal Med 2015; 5(1): 12-9.

28. Forman DE, Butler J, Wang Y, et al: Incidence, predictors at admission, and impact of worsening renal function among patients hospitalized with heart failure. J Am Coll Cardiol 2004; 43: 61-7.

29. Mehran R, Aymong ED, Nikolsky E, et al. A simple risk score for prediction of contrast-induced nephropathy after percutaneous coronary intervention: development and initial validation. J Am Coll Cardiol 2004; 44: 1393-9.

30. Petrović D. Akutno oštećenje bubrega: etiologija, dijagnostika i lečenje. Medicinska Istraživanja 2011; 45(3): 7-13.

31. Aghel A, Shrestha K, Mullens W, Borowski A, Tang WH. Serum neutrophil gelatinase-associated lipocalin (NGAL) in predicting worsening renal function in acute decompensated heart failure. J Card Fail. 2010; 16: 49-54.

32. Pfister R, Müller-Ehmsen J, Hagemeister J, Hellmich M, Erdmann E, Schneider CA. NT-pro-BNP predicts worsening renal function in patients with chronic systolic heart failure. Intern Med J 2011; 41 (6): 467-72.
33. Petrović D, Milovanović D, Miloradović V, et al. Cardio-renal syndrome type 2: Etiopathogenesis, diagnosis and therapy. Med Cas 2012; 46(1): 30-4.

34. Maisel AS, Katz N, Hillege HL, et al. and for the Acute Dialysis Quality Initiative (ADQI) consensus group. Biomarkers in kidney and Heart disease. Nephrol Dial Transplant 2011; 26: 62-74.

35. Shrestha K, Borowski AG, Troughton RW, Thomas JD, Klein AL, Tang WH. Renal dysfunction is a stronger determinant of system ic neutrophil gelatinase-associated lipocalin levels than myocardial dysfunction in systolic heart failure. J Card Fail 2011; 17: 472-8.

36. Campbell CY, Clarke W, Park H, Haq N, Barone BB, Brotman DJ. Usefulness of cystatin $C$ and prognosis following admission for acute heart failure. Am J Cardiol 2009; 104: 389-92.

37. Taglieri N, Fernandez-Berges DJ, Koenig W, et al. Plasma cysta- tin $C$ for prediction of 1-year cardiac events in Mediterranean patients with non-ST elevation acute coronary syndrome. Atherosclerosis 2010; 209: 300-5.

38. Ismail Y, Kasmikha Z, Green HL, McCullough PA. Cardio-renal syndrome type 1: epidemiology, pathophysiology, and treatment. Semin Nephrol Elsevier 2012; 32(1): 18-25.

39. Petrović D, Jagić N, Miloradović V, Nikolić A, Poskurica M, Stojimirović B. Kardio-renalni sindrom u akutnoj dekompenzaciji hronične kongestivne srčane slabosti. U: Kardionefrologija 5. Radenković S, ed. Nis: GIP PUNTA, 2011: 117-26.

40. Felker GM, Lee KL, Bull DA, et al. Diuretic strategies in patients with acute decompensated heart failure. $\mathrm{N}$ Engl J Med 2011; 364(9): 797-805.

41. Ismail Y, Kasmikha Z, Green HL, McCullough PA. Cardio-renal syndrome type 1: epidemiology, pathophysiology, and treatment. Semin Nephrol. Elsevier 2012; 32 (1): 18-25.

42. Remuzzi G, Perico N, Macia M, Ruggenenti P. The role of renin-angiotensin-aldosterone system in the progression of chronic kidney disease. Kidney Int Suppl 2005; 68 (99): S57-65.

43. Sarraf M, Masoumi A, Schrier RW. Cardiorenal syndrome in acute decompensated heart failure. Clin J Am Soc Nephrol 2009; 4: 2013-26.

44. Dittrich HC, Gupta DK, Hack TC, Dowling T, Callahan J, Thomson S. The Effect of KW-3902, an Adenosine A1 Receptor Antagonist, on Renal Function and Renal Plasma Flow in Ambulatory Patients With Heart Failure and Renal Impairment. J Card Fail 2007; 13(8): 609-17.

45. Weatherley BD, Cotter G, Dittrich HC, et al. Design and Rationale of the PROTECT Study: A Placebo-controlled Randomized Study of the Selective A1 Adenosine Receptor Antagonist Rolofylline for Patients Hospitalized With Acute Decompensated Heart Failure and Volume Overload to Assess Treatment Effect on Congestion and Renal Function. J Card Fail Elsevier Inc 2010; 16(1): 25-35. 
46. Konstam MA, Gheorghiade M, Burnett JC, et al. Effects of oral tolvaptan in patients hospitalized for worsening heart failure: the EVEREST Outcome Trial. JAMA. American Medical Association 2007; 297(12): 1319-31.

47. Udelson JE, Smith WB, Hendrix GH, et al. Acute Hemodynamic Effects of Conivaptan, a Dual V1A and V2 Vasopressin Receptor Antagonist, in Patients With Advanced Heart Failure. Circulation 2001; 104(20): 2417-23.

48. Srdjan L, Dejan P. Prevention of acute renal injury in intensive care units. Med Cas 2012; 46(2): 100-4.

49. O'Connor CM, Starling RC, Hernandez F, et al. Effect of Nesiritide in Patients with Acute Decompensated Heart Failure. N Engl J Med 2011; 365(1): 32-43.

50. Lüss H, Mitrovic V, Seferovic PM, et al. Renal effects of ularitide in patients with decompensated heart failure. Am Heart J. Elsevier 2008; 155(6): 1012.e1-8.

51. Dahle TG, Sobotka PA, Boyle AJ. A practical guide for ultrafiltration in acute decompensated heart failure. Congst Heart Failure 2008; 14: 83-8.

52. Bart BA. Congestion in congestive heart failure: ultrafiltration is the only rational initial treatment of volume overload in decompensated heart failure. Circ Heart Fail 2009; 2: 499-504.

53. Udani SM, Murray PT. The use of renal replacement therapy in acute decompensated heart failure. Semin Dial 2009; 22: 173-9.

54. Costanzo MA, Guglin ME, Saltzberg MT, et al. Ultrafiltration versus intravenous diuretics for patients hospitalized for acute decompensated heart failure. J Am Coll Cardiol 2007; 49: 675-83.
55. Rogers HL, Marshall J, Bock J, et al. A randomized, controlled trial of the renal effects of ultrafiltration as compared to furosemide in patients with acute decompensated heart failure. J Card Fail. Elsevier 2008; 14(1): 1-5.

56. Bart BA, Goldsmith SR, Lee KL, et al. Ultrafiltration in decompensated heart failure with cardiorenal syndrome. N Engl J Med 2012; 367(24): 2296-304.

57. Prins KW, Wille KM, Tallaj JA, Tolwani AJ. Assessing continuous renal replacement therapy as a rescue strategy in cardiorenal syndrome 1. Clin Kidney J 2015; 8(1): 87-92.

58. Patarroyo M, Wehbe E, Hanna M, et al. Cardiorenal Outcomes After Slow Continuous Ultrafiltration Therapy in Refractory Patients With Advanced Decompensated Heart Failure. J Âm Coll Cardiol 2012; 60(19): 1906-12.

59. Nohria A, Hasselblad C, Stebbins A, et al. Cardiorenal interactions: insights from the ESCAPE trial. J Am Coll Cardiol 2008; 51: 1268-74.

60. Núñez J, González M, Miñana G, et al. Continuous ambulatory peritoneal dialysis as a therapeutic alternative in patients with advanced congestive heart failure.Eur J Heart Fail. 2012; 14(5): 540-8.

61. Kunin M, Arad M, Dinour D, Freimark D, Holtzman E.J. Peritoneal Dialysis in Patients with Refractory Congestive Heart Failure: Potential Prognostic Factors. Blood Purif 2013; 35: 285-94.

62. Daniela, Marina BB, Cassiana G, André B. Peritoneal Dialysis in Acute Kidney Injury: Trends in the Outcome across Time Periods. PLoS One. 2015; 10(5): e0126436. 